\title{
The Commodity Nature of Labor-Power
}

\author{
GUIDO STAROSTA AND GASTÓN CALIGARIS
}

\begin{abstract}
Some recent Marxist contributions, among them the so-called New Solution to the "transformation problem," call into question the idea of labor-power as a fully-fledged commodity. Yet, the rejection of the commodity nature of labor-power compromises Marx's whole explanation of the origin of surplus-value on the basis of the exchange of equivalents. It can be shown, however, that it is possible to offer a positive case for the commodity-nature of labor-power which is consistent with Marx's broader dialectical investigation of the determinations of the value-form. This requires building upon the arguments that Marx explicitly put forward in his economic works, but also going beyond them, albeit on the basis of those arguments themselves. Furthermore, this novel approach that treats the reproduction of labor-power as a commodity determined by the self-valorization of capital proves to be very valuable in shedding light on two classic Marxist controversies, namely: the debate on domestic labor and the one on skilled labor.
\end{abstract}

\section{Introduction}

I

N A LETTER TO BECKER from April 17, 1867, Marx referred to Capital as "without question the most terrible MISSILE that has yet been hurled at the heads of the bourgeoisie (landowners included)" (Marx, 1987a, 358). Unfortunately, in the rest of that brief note Marx does not clarify the specific sense in which he considered his work to be such a "terrible missile" against the bourgeoisie. However, it seems quite safe to assume that his scientific explanation of the source of capitalist "profit" in the exploitation of wage-workers was among those fundamental aspects of the critique of political economy that he had in mind. As is widely known, the key to this explanation resides in the discovery of the existence of a commodity "whose use-value 
possesses the peculiar property of being a source of value" (Marx, 1976a, 270). This commodity is, of course, labor-power which, "like all other commodities, ... has a value" (Marx, 1976a, 274).

Now, in light of this centrality of the commodity nature of laborpower for Marx's critical investigation of the nature of the capital relation, its rejection can only amount to turning that "terrible missile" against Marx himself. In effect, once we reject the commodity nature of labor-power, then Marx's whole explanation of the origin of surplusvalue on the basis of the exchange of equivalents falls down. As Krätke comments while revisiting the very early critiques of Marx's "unsolved puzzles" in the theory of wages, the "corollary" of such a rejection of the proposition that labor-power is a commodity and has a value "like all other commodities" is "clear and devastating" (Krätke, 2009, 166). Yet, this objection to the commodity nature of labor-power has resurfaced in the last couple of decades. Curiously enough, it has not been advanced by Marx's “detractors" but, as we discuss below, by some of his followers.

A first aim of this article is to critically engage with some of these recent Marxist contributions which, whether they see it as a rectification or ratification of Marx's argument in Capital, call into question the idea of labor-power as a fully-fledged commodity. This is done in the next section, where we review some of the main positions in this contemporary debate. In addition, we subsequently offer a positive case for the commodity-nature of labor-power that builds upon, but also goes beyond, the arguments that Marx explicitly put forward in his economic works. Finally, in order to illustrate the usefulness of this novel take on the determinations of the commodity labor-power, we revisit two classic Marxist controversies that are intimately connected with the central subject matter of this paper, namely: the debate on domestic labor and the one on skilled labor.

\section{Marxist Controversies over Labor-Power as a Commodity}

The objection to the commodity nature of labor-power and, a fortiori, to the determination of its value by the socially necessary labor-time required for its production, can be traced back to the whole series of critiques of Marx that emerged as soon as Volume III of Capital was published. ${ }^{1}$

1 As argued elsewhere (Kicillof and Starosta, 2007a), in its simplest determination privately undertaken labor is socially necessary (hence value-producing) if it satisfies two conditions: first, it corresponds to the technologically normal conditions of production prevailing in 
Thus, already in 1907 Bortkiewicz argued that since there is no "competition between producers" of this commodity, wages cannot be subordinated to "the general law of value" and therefore its value cannot be determined in the same way as the value of other commodities (Bortkiewicz, 1952, 57). Strictly speaking, this first line of criticism mainly and explicitly revolved around the denial of the existence of an adjustment process of the price of labor-power to the average socially necessary labor-time for the production of this particular commodity. However, insofar as in Bortkiewicz's Ricardian approach there was no clear distinction between the price and the value of labor-power, the implausibility of such an adjustment mechanism implicitly called into question the very foundations of the value-content of labor-power. In fact, Bortkiewicz concluded that real wages had to be taken as fixed (Bortkiewicz, 1952, 57). According to Krätke, Tugan-Baranowsky went even further and argued that "labor power was not a commodity at all, wages could not be considered a 'value phenomenon' and Marx's theory of wages was outright wrong or just tautological” (Krätke, 2009, 169). Yet, as Krätke also reports, Marxists at that time did not respond to the challenge (Krätke, 2009, 166).

Although similar arguments emerged later in the 20th century, and on this occasion among scholars who were otherwise sympathetic to Marx's ideas (e.g., Castoriadis, 1988; Bowles and Gintis, 1981), it has been in relatively recent times that the objection cropped up within the specialized Marxist literature. Moreover, in many cases the objection to the commodity nature of labor is not seen just as a correction to an allegedly inadequate treatment of the subject by Marx, but is even presented as a reflection of Marx's own views.

This rejection of the commodity nature of labor-power and, consequently, of Marx's account of the determination of its value, has come from rather disparate traditions. The so-called systematic dialectics strand of value-form theory is a case in point. Thus, Chris Arthur takes "distance from Marx's attempt to treat labor power as a produced commodity subject to the law of value" (Arthur, 2006, 90). More specifically, he states that "wage-labor should be treated in the same way as landed property, namely as a material presupposition of

society (Marx, 1976a, 129), and, second, it can satisfy a social need (Marx, 1976a, 131), regardless of whether that need arises from "the stomach or the imagination" (Marx, 1976a, 125). In other words, only under those two circumstances is the objectification of the abstract character of private labor socially represented in the form of value. 
capitalist production, which is rewarded with part of the value created in production, namely the wage" (Arthur, 2006, 90; see also Reuten and Williams, 1989, 68; and Roblez Baez, 2011, 26-27n).

Still, the most remarkable case is that of the so-called "New Solution" or "New Interpretation" to the "transformation problem" (Foley, 1982; Lipietz, 1982; Dumenil, 1983). In effect, unlike the rather incidental role played by the rejection of labor-power as a "genuine commodity" among "new dialecticians," for these other scholars it constitutes one of the pillars on which their whole theoretical construction is based. On the other hand, their arguments have already been critically examined quite sharply by other Marxist scholars (Mavroudeas, 2001; Fine et al., 2002), which provides us with a firmer basis to develop our own arguments.

Perhaps the clearest formulation of the New Solution's corollary about the commodity nature of labor-power can be found in the work of Simon Mohun. According to this author, labor-power

is not a produced commodity in the same sense [as other commodities]. It is a capacity or potentiality of people, and people are not (re) produced under capitalist relations of production. No capitalist production process is involved, no process of adding value to the means of production by living labor; neither do there exist different technologies of production in competition with one another which must be averaged to find a market value. (Mohun, 1994, 398.)

For this reason, Mohun continues, Marx's own definition of the value of labor-power is not given in terms of the labor-time required for its production but "in terms of the value of the commodities which the money-value of labor-power can purchase, or command" (Mohun, 1994, 398). It is this novel conception of the value of labor-power that provides one of the keys to this approach's specific solution to the "transformation problem." In effect, under this new definition, the value of labor-power is determined as the part of total value-added represented by the wage share. However, through an idiosyncratic formal procedure, they still conclude, in a roundabout way, that the money-wage represents a determinate quantity of socially necessary abstract labor.

The first step in the New Solution's construction is to posit an "immediate equality between the total price of the net product and the total living labor performed in each period" (Mavroudeas, 2001, 
59). On this basis, these authors subsequently obtain the "monetary expression of labor" (MEL) as the ratio between the total price of the net product and the total hours worked. The MEL thereby allows them to transform money-prices into "labor-values." In the case of labor-power, its "value" expressed in "labor-time" is calculated by multiplying the rate of money-wages by the MEL. Through this peculiar procedure, these scholars consider that they avoid the problem of transforming variable capital and, as a consequence, that they offer a way to sidetrack the divergence between total profits and total surplus value. However, this "solution" to the "transformation problem" comes at the cost of parting company with Marx's own definition of the value of labor-power as determined by "a definite quantity of the average social labor objectified in it" (Marx, 1976a, 274). As Foley puts it in his seminal contribution to the New Solution, "the value of labor power, in this perspective, is the fraction of the total abstract social labor time claimed by workers in the form of the wage" (Foley, 1982, 42; see also Mohun, 1994, 403). Although not all supporters of the New Solution explicitly draw the conclusion that this entails the rejection of the commodity nature of labor-power, we will see below that this is the necessary implication of this approach.

As mentioned above, this conception of the value of labor-power has been strongly criticized by other Marxist scholars. In our view, Mavroudeas' (2001) critique stands out as probably the sharpest and most illuminating. According to this author, there are several shortcomings in the New Solution approach. In the first place, this approach violently abstracts from the intermediate steps that lead from socially necessary labor for the reproduction of workers to the value of laborpower. Specifically, it "discards the intermediation of a set of use-values (and their value) between necessary labor-time and money-wages and proceeds to link them directly" (Mavroudeas, 2001, 59). The upshot of this is that the "New Solution's conception of the value of labor-power ends up with a Smithian labor-commanded conception of value rather than one based on abstract labor" (Mavroudeas, 2001, 59). In turn, this has the consequence of grounding the quantitative determination of the value of labor-power in extra-economic factors which, "when this is supplemented with the rejection of the commodity-nature of labor-power, then it can easily lead to a prioritization of power relations independently and almost prior to socio-economic relations" (Mavroudeas, 2001, 55). In effect, regardless of the New Solution's 
claim that in their conception the value of labor-power still represents a share of the total abstract labor performed, it is self-evident that a "value" that is not the objectification of the social determinations of the material production process of the commodity that acts as its "bearer," can hardly be taken as synonymous with what Marx termed the "value of a commodity." Thus, the New Solution's eventual rejection of the commodity nature of labor-power is the other side of the same coin of their idiosyncratic conception of the determination of its value.

However, as Saad-Filho argues, despite the weaknesses of the New Solution, it is not easy to find a solid alternative within the Marxist literature (Saad-Filho, 2002, 48 ff). Most other contributions relapse into an equally problematic Ricardian or "labor-embodied" approach. At its most extreme, this perspective tends to assume an immediate identity between the value of labor-power and a "fixed" bundle of means of subsistence. But even in its more nuanced versions, this conception does not seem able to account for the determination of the composition of those "wage-goods," their historical changes or the wage differential among different segments of the working class (Fine, 1988, 180). Moreover, this Ricardian approach eventually ends up reifying workers, as if they were "slaves, beasts of burden [or] machines" (Saad-Filho, 2002, 48) and, as a consequence, renders arbitrary the very concept of "exploitation" (Fine et al., 2002, 11).

In order to overcome the limitations of both the New Solution and neo-Ricardianism, Fine et al. come up with a third alternative whose main thrust is that "the value of labor power is neither a quantity of money nor goods but a quantity of value" which, in turn, is determined "at the aggregate level through the exchange between capital and labor as a whole (i.e., as social classes), prior to the process of production" $(2002,12)$. Now, although it is correct that the value of labor-power is already determined prior to the process of production which follows the capitalist's purchase of that "peculiar commodity," this analysis does not take us very far from a mere repetition of what Marx explicitly wrote in Capital. In other words, this position amounts to just asserting the connection between the value of labor-power and the value of means of subsistence without demonstrating it. No actual explanation of that relationship is offered other than the invocation of Marx's texts. Maybe aware of this, these authors state that a proper full explanation of the value of labor-power needs to reconsider it at more complex levels of analysis. For instance, this requires the 
dynamic redefinition of the bundle of wage-goods resulting from the development of the productive powers of labor. Indeed, the accumulation of capital "tends both to redefine (lower) the value of labor power and (increase) the wage bundle" (Fine et al., 2002, 12). Furthermore, "consumption norms" vary greatly across the different categories of workers, so that it makes no sense to posit an "average" consumption bundle which would determine the value of labor-power "in general" (Fine et al., 2002, 12).

It seems to us that this alternative position does not succeed at fully overcoming the weaknesses of its opponents. First and foremost, these authors do not actually offer a clear and precise explanation of the determination of the value of labor-power "in general." Instead, they just sidetrack the problem by invoking the need to incorporate more complex phenomena. Furthermore, methodologically speaking, it is quite simply incorrect to argue for the impossibility to fully resolve the question of the value of laborpower "in general" given the complexity of its concrete forms of realization. It is not only possible but necessary to treat and settle the question at the level of the simpler or more abstract determinations of capital. ${ }^{2}$ In fact, Marx himself made this methodological point in the Economic Manuscripts of 1861-1863 when justifying the initial abstraction from the determinants of the value of laborpower attributable to its complexity, since

important as the latter consideration becomes when it is a matter of analysing the differing values of individual branches of labour, here it is irrelevant, for we are only concerned with the general relationship between capital and labour, and therefore have in view ordinary, average labour, seeing all labour as only a multiple of this average labour, the training costs of which are infinitesimally small. (Marx, 1988, 43.)

2 In this sense, the issue under discussion in this paper pertains to the "level of abstraction" of Volume I (i.e., to the social form of the process of production), and is analytically separable from the concrete forms assumed by the establishment of the unity of the movement of the total social capital in circulation (i.e., the "level of abstraction" of Volume III, including the so-called "transformation problem"). In other words, this is a problem pertaining to value-production and not to its distribution. However, one implication of our argument is clear in this regard. If one concludes that labor-power is a fully-fledged commodity and has a value determined "like any other commodity," the value of variable capital does need to be transformed into the concrete form of price of production (a task which evidently exceeds the scope of this paper). As a consequence, we think that the alleged solution of the New Interpretation is no solution at all. 
In this sense, although otherwise writing from a similar perspective to the one just sketched out, Mavroudeas' aforementioned contribution offers more elements both to explain the relationship between the value of means of subsistence and the value of labor-power, and to overcome the shortcomings of the New Solution approach. Regarding the latter, this author rightly claims that commodity values must be explained by their content (i.e., by socially necessary labor-time required for their production) and not by their form (i.e., by the ratio in which they exchange against money in circulation). And although he admits that labor-power is a "peculiar" commodity ("since it only exists as a capacity of the living individual ... which is commodified in capitalism"), he argues that it does not follow from this that it is "a natural good that enters the market without any value, acquiring there a price" (Mavroudeas, 2001, 56). Mavroudeas thereby proceeds to analyze the production process of labor-power and makes two additional points. First, he agrees with New Solution scholars like Mohun that no new value is added in the "domestic" sphere of reproduction of labor-power on the very same grounds: the reproduction of labor-power entails "human effort but this is not expended through a capitalist production process," the upshot of which is that "there is no creation of new value or surplus-value and the sale of the commodity labor-power does not operate according to the rules of typical capitalist commodity exchange (obtaining an average rate of profit etc.)" (Mavroudeas, 2001, 56). Second, however, he also argues that the means of consumption required for the reproduction of laborpower are capitalistically produced by wage-labor and bought in the market, which means that they have a value determined by socially necessary labor-time. Crucially, and here Mavroudeas goes beyond what Marx explicitly states in Capital, he further submits that the value of the means of "subsistence" is transferred to labor-power through the workers' consumptive activity and therefore "this value has to be reflected in the price that is paid for buying labor-power (wage)" (Mavroudeas, 2001, 56).

There are three problems with this defense of Marx's argument on the value of labor-power. In the first place, it has no textual basis in Marx's exposition in Capital; not because he explicitly states otherwise, but because he does not discuss the question at all. Presumably, Marx took for granted that in light of the determinations already unfolded by chapter 6 , it would be self-evident for readers why "human effort" 
expended in the domestic sphere could not be value-positing. As he unambiguously puts it in the section on commodity fetishism in chapter 1 , "objects of utility become commodities only because they are products of the labor of private individuals who work independently of each other" (Marx, 1976a, 165). This leads us to the second problem.

For while Mavroudeas is right to point out that no new value is posited in the domestic sphere of individual or personal consumption, the grounds that he offers for that claim (which he shares with the New Solution) are essentially wrong. The expenditure of human labor-power within the domestic sphere does not create value not because it is not "expended through a capitalist production process with a view to obtaining the average rate of profit." The reason lies in the fact that the organization of the allocation of that portion of social labor in its particular concrete forms which takes place within the "household" is not mediated through indirect social relations between private and independent individuals (which, as argued elsewhere (Kicillof and Starosta, 2007a; 2007b; Starosta, 2016), is the ground of value-positing activity). The allocation of social labor within the domestic sphere is organized through direct, personal relations (the family). In other words, that portion of social labor does not possess "the peculiar social character of the labor which produces [commodities]" (Marx, 1976a, 165)..$^{3}$

Finally, although we shall see that Mavroudeas' point about the "transfer" of value from the means of consumption to the wageworker's labor-power is broadly on the right track, he does not offer a convincing explanation of why and how this material and social process occurs. ${ }^{4}$ Note, however, that neither does Marx's own presentation

3 Of course, all products of capital are commodities, and only in the capitalist mode of production social wealth universally takes on the commodity-form. Yet, it does not follow that the value-form of social wealth is grounded in the fact that it is immediately ruled with a view to valorizing an individual capital. The simplest determination of the value-form is given at the level of abstraction of the commodity as a presupposition of capital. This is what grounds the content of the value-determination. By contrast, commodity production under the command of an individual capital with a view to obtaining the average rate of profit (i.e., the commodity not as a methodological-systematic premise but as result of the movement of capital) determines the concrete form in which value is realized (i.e., the price of production). For a methodological discussion of the commodity as presupposition and result of capital, see Marx, 1976b, 953ff.

4 The reason given by Mavoudeas is that "contrarily to consumption goods consumed by capitalists (luxuries), workers' consumption is a productive activity and they transfer their value to the commodified aspect of human reproduction (labor-power)" (Mavroudeas, $2001,56)$. At least on the basis of this statement alone, it is not clear to us in what sense the workers' consumption is a productive activity. 
in Chapter 6 of Capital spell out, in any systematic fashion, the way in which the connection between the value of means of subsistence and the value of labor-power becomes concretely established over the course of the process of reproduction of the wage-worker. The link is just asserted. In order to make that connection explicit, we need to go beyond what Marx said on the question in Capital, albeit on the basis of determinations that are perfectly in line with his argument in the rest of the book.

\section{The Value of Labor-Power}

A first relevant element for this discussion can be found in the Economic Manuscripts of 1861-1863. In that text, in the context of a critique of Bailey's "silly" ( $\mathrm{sic}$ ) objection to Ricardo's determination of the "value of labor," Marx makes the point, not mentioned in Capital, that the determination of the value of labor-power by the value of the means of subsistence is not peculiar to that particular commodity but applies to all "organic" commodities; for instance, it applies to the value of animals as well (Marx, 1988, 48). Moreover, he makes clear that the way in which the means of subsistence enter in the "price of labor capacity" is through the "metabolic process," i.e., through the "exchange of matter" involved in the process of individual consumption of those means of subsistence by the bearer of human labor-power.

The price of сLотн does indeed consist also of the price of the cotton yarn consumed in it, just as the price of labor capacity consists of the means of subsistence that enter into it through the metabolic process. Incidentally, the reproduction of living, organic things does not depend on the labor directly applied to them, the labor worked up in them, but on the means of subsistence they consume - and this is the way of reproducing them. Bailey could also have seen this in the determination of animals' value; even in the case of machines, in so far as coal, oil and other matières instrumentales consumed by them enter into their cost. . . . Otherwise Bailey's joke only has the upshot that the labor applied to the reproduction of the organic body is applied to its means of subsistence, not directly to the body itself, since the appropriation of these means of subsistence through consumption is not work but rather enjoyment. (Marx, 1988, 48.)

In other words, the "transfer" of the value of means of subsistence to the commodity labor-power takes place through the material change 
of form of those use-values into the bodily (physical and intellectual) productive attributes of the wage-worker. Similarly to the transfer of the value of means of production to the final product, one could say that the value of means of subsistence, as Marx puts it, "undergoes a metempsychosis" (Marx, 1976a, 314). Through this "transmigration," value "deserts the consumed body to occupy the newly created one" (Marx, 1976a, 314). The analogy, however, stops here.

For unlike means of production, labor-power is not, in and of itself, a use-value (Iñigo Carrera, 1995, 5). ${ }^{5}$ In other words, it is not in itself a means for human life, "a thing that through its qualities satisfies human needs of whatever kind" (Marx, 1976a, 125), although its existence is clearly a condition for the specifically human process of material metabolism. However, although human labor-power is not a use-value by its own material nature, it becomes form-determined as such when subsumed by capital as the active condition for its valorization. In effect, given the private form taken by social production, labor-power embodies the capacity to produce value and, more specifically, more value than it costs. (Surplus) value-positing for capital becomes its form-determined use-value. ${ }^{6}$ Thus, it is the constitution of the value-form into the alienated subject of social life that turns labor-power into a use-value, by determining the exercise of that human capacity as the immediate source of its self-expansion.

As Marx shows in Chapter 23 of Volume I on "Simple Reproduction," the constitution of the total social capital into the subject of the movement of society reaches its plenitude when subsuming material reproduction in its unity, i.e., when it subordinates not only social production and circulation, but also the process of individual consumption (Marx, 1976a, 711ff). As a consequence, the unity of the human

5 Note that transformation of the use-value of means of production into a new use-value is for Marx a necessary condition for the "transmigration" of their value to take place: "The reason why means of production do not lose their value at the same time as they lose their use-value is that they lose in the labor process the original form of their use-value only to assume in the product the form of a new use-value. But however important it may be to value to exist in, it is still a matter of complete indifference what particular object serves this purpose" (Marx, 1976a, 310).

6 This, we take it, is the meaning of the following passage from the original text of $A$ Contribution to the Critique of Political Economy: "For money as capital, labor capacity is the immediate use value for which it has to exchange itself. In the simple circulation, the content of the use value was indifferent, dropped out of the economic determination of form. Here it is its essential economic moment. For the exchange value is determined as firmly established in exchange above all because it is exchanged with a use value confronting it in its own form determination" (Marx, 1987b, 504). 
metabolic process becomes inverted into a moment of the reproduction of capital. The implication of this is that in capitalist society the process of individual consumption does not bring each cycle of the process of metabolism to a close. In other words, in the capitalist mode of production individual consumption in the domestic sphere is not synonymous with final consumption, as economics, both "classical" and "vulgar," would have it (Ricardo, 1821, 339; Jevons, 1871, 47; Keynes, 1936, 104). The latter moment is reached in the sphere where labor-power is consumed for the production of more value than its reproduction costs, i.e., in the phase of productive consumption or the labor process. This is crucial for the link between the privately undertaken socially necessary abstract labor-time materialized in the means of subsistence and the value of labor-power. Let us examine the matter more closely. ${ }^{7}$

The workers buy those means of consumption in order to reproduce their life as social subjects. In doing so, the value objectified in them is realized since the private labor that had been expended on them is confirmed as socially necessary. Those use-values are then taken to the domestic sphere of individual consumption, where they are either consumed straightaway if their materiality was immediately apt for the satisfaction of a human need, or subject to a further labor process. However, we have seen that in this latter case the objectification of social labor does not result in its representation in the social form of value.

Now, when those use-values are consumed, their materiality does not simply vanish but only changes form into reconstituted laborpower which, as argued above, is not in itself a use-value. Hence, if the immediate aim of the social reproduction process were the reproduction of human life (as would happen with a simple circulation of commodities), this transformation of the materiality of means of consumption into productive attributes of the human subject would bring this particular cycle of social reproduction to a close. Thus, even if those use-values had the commodity-form, their value would disappear definitively with that consumptive appropriation of their materiality.

However, we have further argued that from the point of view of the alienated organization of human life as an attribute of capital, that

7 In what follows we draw on Iñigo Carrera, 1995, 6-7. 
process does not close the cycle of social reproduction, but is only a passing moment in the process of value's self-valorization. Thus, the commodities consumed by the wage-worker must be turned into the production of his/her particular labor-power, that is, into the determinate productive attributes that the material conditions for the valorization of capital determine as a new use-value. Hence, from the general social point of view, the new form which those means of consumption acquire by being transformed in the renewed labor-power of the wageworker still needs to prove socially necessary, which in this context does not mean that it is capable of satisfying a human want, but that it is able to valorize capital. In other words, the confirmation that the portion of social labor originally allocated privately in the particular concrete form of those means of consumption was socially useful entails a further mediation, namely: the success of the wage laborer at selling his/her labor-power as a commodity, i.e., as a use-value that has been produced in a private and independent manner from the point of view of the form-determined content of the unity of the social metabolic process. This is why the value borne by those means of subsistence does not disappear with their consumption in the household but reappears as the value of labor-power. If the latter is effectively sold, then the social labor expended in the production of the means of consumption which the worker had consumed to reproduce labor-power is eventually confirmed as socially useful.

Still, this does not yet bring the cycle of that commodity to an end. The realization of its use-value is still pending, a process that can only occur through its consumption. Therefore, only when the latter is effectively consumed (i.e., exploited) by capital in the immediate production process as a specific use-value which is capable of producing surplus-value, that particular cycle of social reproduction is brought to a close. It is only at that stage that the use-value of labor-power (and so the changed form of the original means of consumption) suffers final appropriation and, with that, its value is eventually extinguished. On the other hand, that very consumption of labor-power by capital privately produces new commodities and hence, new value and surplus-value.

In sum, this discussion shows that there is a necessary material link between socially necessary labor-time expended in the production of means of subsistence and the value of labor-power. Although the mediations that connect the value of means of subsistence with 
the value of labor-power are not fleshed out by Marx, it is possible to establish that nexus in a way which is absolutely consistent with the general determinations of the value-form that he did present in Capital. In effect, we have shown that, with the proviso about the form-determined nature of its use-value, all the determinations of the commodity-form are present in the production of labor-power. Paraphrasing Marx, a "definite quantity" of privately undertaken socially necessary abstract labor "is objectified in it." That objectification of labor-time must therefore take on the value-form in order to manifest its general social character. The objections of critics to the commoditynature of labor-power are therefore unfounded.

In light of this conclusion, in the next couple of sections we turn to the discussion of two classic Marxist controversies that touched upon the production process of labor-power: the debates on "domestic labor" and on "skilled labor." As we shall see, our approach to the reproduction of labor-power as commodity determined by the selfvalorization of capital will prove to be very valuable in shedding light on many of the contentious issues involved in those debates.

\section{The Domestic Labor Debate}

This debate was motivated by the perceived need to investigate more thoroughly the labor process performed within the wage-worker's household (Benston, 1969; Morton, 1971). In the view of most of the participants, this task had not been undertaken satisfactorily within Marxism (Vogel, 2000, 156). Following on from Dalla Costa and James' contribution (1972), the attention of many scholars subsequently turned to Marx's argument about the quantitative determination of the value of labor-power. More specifically, several works made a case for the reconsideration of domestic labor as value-producing. Two different but converging arguments were put forward. In the first place, some authors argued that domestic labor is part of socially necessary labor for the production of labor-power and must therefore enter into the quantitative determination of its value and be reflected in the wage (Secombe, 1974). A second approach postulated that domestic labor is not immediately represented as the value of labor power, but indirectly as capital's surplus value or profit. In its more sophisticated version, this perspective maintained that the surplus labor of the domestic worker is appropriated by capitalists through 
the exchange of labor-power against a wage that does not pay for all the labor-time "objectified" in it (Harrison, 1973; Gardiner, 1976).

Various objections were raised against this broad "heterodox" perspective, the main one being that domestic labor is not subordinated to the law of value insofar as it is neither performed under capitalist relations of production (Himmelweit and Mohun, 1977), nor organized with a view to exchange (Smith, 1978). Hence, these critiques went on, concrete labor performed in the household cannot be reduced to socially necessary labor and therefore cannot be value-producing. In sum, these critics rejected the validity of the social identification of domestic and wage labor, which is precisely what the original contributions had assumed. Now, although we concur with these critics that it is incorrect to consider domestic labor as (surplus)value-producing, those original contributions had nonetheless the merit of providing an in-depth and detailed examination of the processes involved in the (re)production of labor-power. In some cases, those contributions even hinted at the aforementioned problem of the "transference" of the value of means of subsistence into the commodity labor-power. As a matter of fact, the pioneering work by Inman from the 1940s had already submitted that "the value of the commodities consumed by the worker's family . . . reappear[s] again on the market, but in a new form, as the commodity labor-power" (Inman, 1942, 45, cited in Thomas, 1987, 331). As mentioned above, this insight is crucial for the determination of the value of labor-power by the socially necessary labor objectified in the means of subsistence and, a fortiori, for the commodity-nature of labor-power.

Be that as it may, the point is that as a result of this debate, many Marxist scholars were led to question Marx's overall argument regarding the determination of the value of labor-power. Thus, Philip Harvey (1983, 308-310) suggested that if the value of means of subsistence reappears in the value of labor-power, this necessarily means that the workers' individual consumption is in reality a labor process, which utilizes those means of subsistence as means of production of laborpower. But if this is the case, Harvey continues, this "labor of productive consumption" must be considered as socially necessary for the production of labor-power. And the same goes for domestic labor that further transforms means of subsistence originally purchased as commodities with the wage. On these grounds, and in the face of the fact that Marx did not include these expenditures of human bodily powers 
in the determination of the value of labor-power, Harvey concluded that Marx's approach does not actually constitute a "labor theory" of the value of labor-power but a "cost of production theory" (P. Harvey, $1983,307,312)$. In other words, the value of this "peculiar commodity" is not, pace Marx, determined "as in the case of every other commodity" by the "labor-time necessary for the production ... of this specific article" (Marx, 1976a, 274). ${ }^{8}$

From our perspective, these analyses reach these problematic conclusions because they overlook the essential determination at stake in the transference of value between different use-values, namely: the need to re-validate the social character of privately performed labor. This is a process that is generally mediated by productive labor but that, in the context of the overall movement of reproduction of the total social capital, takes place as well through individual consumption. As argued at great length above, the abstract character of privately performed labor objectified as the value-form of means of subsistence does not attain definitive recognition as socially necessary at the moment of their purchase by the working class family. This only occurs when the capitalist buys their labor-power with the aim of valorizing his/her capital and subsequently consumes them productively in the direct production process. Only at that point is the formal use-value of labor-power finally extinguished and its value therefore disappears. Hence, the reappearance of the value of means of subsistence as the value of labor-power simply expresses the need to reassert, under the new guise assumed by those use-values, the social character of the privately performed labor originally objectified in them. In other words, this "transfer of value" is quite simply derived from the general determination underlying the value-form of the product of labor: it is the reified form through which the immanent social determinations of human productive activity are represented when they are indirectly organized through the general production and exchange of commodities.

Why, then, is the labor performed in-between the wage-worker's purchase of means of subsistence and the sale of labor-power not

8 Some years later, Thomas $(1987,127)$ tried to avoid these conclusions by arguing that the only labor that transfers value is "commodity-producing, value-creating labor." Hence, Marx's argument needed to be amended in order to incorporate the fact that domestic labor produces value. In this way, she reinstated the feminist critique that considered Marx's approach as incomplete (if not directly flawed). 
represented as its value? The answer to this question cannot just come down to saying, as in most critiques of the "heterodox" camp in the debate, that "domestic labor" is not subordinated to the "law of value." As a matter of fact, this is precisely what needs to be explained. Thus, the reason why this labor is not value-producing is that it is not private labor vis-à-vis the immediate consumer of its product. And note that this applies both to reproductive labor undertaken by the worker him/ herself (which is not even social labor) and to work performed by other family members (which is social since it is done for another individual, i.e., the wage-worker, but directly so, i.e., its social character is organized through personal social relations). This point can be further clarified through a comparison with the domestic labor undertaken by a hired cleaner or cook. In the latter case, it does create value, since we do have an instance of privately performed social labor vis-à-vis the immediate consumer of its product, which thereby does take the commodity-form (as much as the labor that, for instance, produces the meals that the worker eats at a restaurant; the fact that the former occurs in the household is immaterial). As a consequence, the "domestic labor" performed by a hired cleaner or cook does enter into the determination of the value of labor-power. ${ }^{9}$ Thus, the feminist normative claim that reproductive labor be considered as value-producing is revealed as underpinned by an essentially ahistorical or Ricardian conception of value, insofar as it considers that all productive expenditure of labor-power is value-producing regardless of its "peculiar social character" (Marx, 1976a, 165).

In sum, it is perfectly possible to explain the parts respectively played by the domestic productive and consumptive processes in the

9 In this sense, it must be acknowledged that Marx's presentation in Capital is not entirely satisfactory in this regard. Thus, he claims that labor-power has value like all other commodities because "it represents no more than a definite quantity of the average social labor objectified in it" (Marx, 1976a, 274). For the sake of rigor and clarity, he should have actually referred to "privately undertaken average social labor objectified in it." In other words, only commodities (and not simply use-values) consumed by workers enter into the determination of the value of labor-power. In Marx's defense, it was probably a shorthand expression which, even if not entirely correct, was seen by him as harmless in light of the rigorous and lengthy exposition of the determinations of the commodity-form contained in the first section of Capital (cf. his remark on overlooking the difference between value and exchange-value for the sake of brevity once the dialectical exposition has established their "unity and difference"). Besides, in the Economic Manuscripts of 1861-1863 he made the point explicitly: in its general determination, "the means of subsistence needed for the maintenance or reproduction of labor capacity can all be reduced to commodities" (Marx, 1988, 43). 
formation of the value of labor-power, on the basis of Marx's "valueform theory." All privately undertaken socially-necessary labor for the production of this "peculiar commodity" is represented as its value, while all directly social necessary labor is not. Therefore, the critique of Marx's analysis of the value of labor-power stemming from the "domestic labor debate" is ill-founded. The lack of conceptualization of this labor in the determination of value is not a "blind spot" of the Marxian critique of political economy (Werlhof, 1988). It is perfectly consistent with the "purely social objectivity" of the value-form that Marx discovered.

\section{The Skilled Labor Debate}

The question about the kind of labor expended to produce laborpower and, more specifically, about its preservation or destruction in subsequent phases of capital's overall circulation process has been at the center of another important controversy within Marxism, namely: the skilled labor debate. In this section, we review the main positions in the debate and offer some reflections on the way in which our reconsideration of the determinations of the commodity-nature of labor-power can shed light on many of the apparent difficulties posed by the "multiplied" value-producing powers of skilled labor.

The debate on skilled labor was initiated by Böhm-Bawerk's wellknown criticism of Marx's value-theory (Böhm-Bawerk, 1890; 1949). According to this author, the Marxian explanation of the equalization of qualitatively different labors fails because the argument unfolds "in a complete circle": it starts out in search for an explanation of the exchange relation but, insofar as it is argued that "the standard of reduction [of skilled to simple labor] is determined solely by the actual exchange relations themselves," it ends up accounting for the exchange relation on the basis of that very same exchange relation! (BöhmBawerk, 1949, 83). The first line of reply provided by Marxists was that the greater value of the product of skilled labor is not explained by the exchange relation, but by the greater value of more complex labor-power. According to this conception, the higher the value of labor-power, the greater will be the magnitude of value that results from its objectification (Bernstein, 1900).

However, other Marxists very soon took this explanation to task for relapsing into a theory of value founded on "costs of production." 
As Hilferding noted, Bernstein's explanation wanted "to deduce the value of the product from the 'value of labor'" (Hilferding, 1949, 141). As an alternative, Hilferding and other authors proposed a procedure for the reduction of skilled to simple labor based on the addition of the quantities of simple labor that materialized in the production of skilled labor-power and which, indirectly, become "condensed" in the actual expenditure of the latter. More specifically, according to these authors these "formative labors" included both the work of the "technical educator" (Hilferding, 1949, 144) and that of the skilled laborer (in his/her capacity as student) (Bauer, 1906). Those past formative labors, Hilferding states, "are stored up in the person of the qualified laborer, and not until he begins to work are these formative labors made fluid on behalf of society" (Hilferding, 1949, 144).

Until the mid-1970s, the Hilferding-Bauer approach was widely accepted by Marxists as the definitive response to Böhm-Bawerk (e.g., Sweezy, 1942; Meek, 1956; Rowthorn, 1974). However, soon after that some Marxists started to raise some reservations against the alleged solution to the "reduction problem." In the first place, it was argued that the HilferdingBauer reduction procedure implied different rates of surplus value for skilled and simple labor which, it was claimed, contradicted the Marxist theory of exploitation (Morishima, 1973). Second, other scholars argued that in conceiving of the worker's skills as the material condensation of past labor that would subsequently be represented in the higher value of the product, the productive attributes of workers were treated as constant capital (Tortajada, 1977). In relation to the first of these objections, let us note that the existence of different rates of surplus value leaves the general qualitative determination underlying the exploitation of wage-workers untouched. In effect, regardless of the relative complexity of his/her labor-power, each worker performs (on average) as much labor for capital as the normal long-term reproduction of his/her labor-power allows. And he/she receives in exchange an equivalent of the socially necessary labor time for the reproduction of those productive attributes that capital demands from him/her. The fact that this might result in different rates of surplus value for labor-powers of different qualifications only affects the degree in which capital will appropriate unpaid surplus labor. But it does not compromise the validity of Marx's explanation of the source of surplus value in the exploitation of the wage-worker. Furthermore, these varied rates of surplus value are immaterial for 
the individual capital, insofar as it could be argued that this is but another differential condition of valorization that becomes averaged out through the formation of the general rate of profit (similarly to differences in the organic composition or turnover rates).

By contrast, the second objection does pinpoint a real flaw in the traditional "reduction method," insofar as the latter involves a departure from the general determinations of value and surplus value. More specifically, it parts company with Marx's argument that it is only the expenditure of the living labor of the worker that posits new value in the product, while the value of constant capital (i.e., "past labor") is only "transferred" in the same magnitude. In postulating that the value of the product of skilled labor includes the "past labor" materialized in the more skilled labor-power, the classic solution ends up effectively conflating constant and variable capital. On this score, we concur with those who rejected the Hilferding-Bauer train of thought.

In the face of these shortcomings of the traditional reduction procedure, new alternative solutions appeared that changed considerably the very terms of the problem without, however, achieving any consensus. Thus, some scholars proposed that the reduction of skilled to simple labor should be regarded as a real and observable process of de-skilling of labor-power resulting from capital's transformation of the labor process (D. Harvey, 1982; Itoh, 1987; Carchedi, 1991), while others opted for considering skilled labor quite simply as more productive (P. Harvey, 1985; Bidet, 2007; Saad-Filho, 2002). In our view, rather than solving the "skilled labor" reduction problem, these alternative just sidestep it. By contrast, we think that our approach to the determination of the value of labor-power sketched out above offers a valuable and novel way to critically examine the classic HilferdingBauer reduction procedure and to develop a more rigorous explanation of the "multiplied" value-creating powers of skilled labor.

In the first place, having demonstrated that labor-power is a fullyfledged commodity we know with certainty that its value is exclusively determined by the privately performed socially necessary abstract labor required for its production. Moreover, insofar as capital's productive consumption of labor-power closes the form-determined cycle of social reproduction, this value disappears through the expenditure of the worker's living labor in the direct production process. 
Consequently, regardless of the degree of complexity embodied in the worker's labor-power, no single "atom" of its value can be preserved and transferred to the product of his/her labor. In this sense, the labor of the "technical educator" or the labor objectified in a textbook are hardly different from those labors objectified in the most prosaic of commodities that the worker consumes during his/her lunchtime. Assuming that they have the commodity-form, they are all part of the privately undertaken socially necessary labor required for the production of the commodity labor-power and, in that condition, they are absolutely independent of the labor that the worker will perform when setting his/her labor-power into motion in the capitalist labor process.

Now, Hilferding-Bauer and their followers obviously think that their reduction procedure avoids Bernstein's error of grounding the value of the product of skilled labor in the value of skilled labor-power. However, it seems to us that by including in the value of the product of skilled labor the socially necessary labors required for the production of skilled labor-power, they end up relapsing into a similar elementary mistake, namely: conflation of the value of labor-power (the "past labor" objectified in it) and its use-value (the value-positing capacity of living labor in action). As stated above, there can be no trace of the past labor required for the production of skilled labor-power in the "multiplied" value-positing powers of skilled living labor in action. The central question still stands unanswered: how is the higher value of the product of skilled labor explained?

Again, here we think that the answer must be: "as in the case of any other commodity," i.e., by the privately performed socially necessary abstract labor required for its production. The key, of course, resides in being absolutely clear and precise about which private labors are socially necessary just for the production of the product of skilled labor. And these come down to the living labor of the skilled worker, the "dead" labor objectified in the means of production consumed by living labor in the capitalist production process and, crucially, the labor expended by the skilled laborer himself/herself (i.e., not by the "technical educator") with a view to acquiring the skills that are socially necessary for the production of the said commodity. As we have seen, the latter is a kind of labor which, insofar as it is not private from the point of view of the production of (skilled) labor-power, does not enter into the determination of its value. However, it definitely is private and socially necessary from the perspective of the production of the use-value that 
the skilled laborer will produce under the command of the capitalist. For that reason, it enters into the value of the product of skilled labor.

Clearly, this admittedly succinct answer does not address all the complexities and subtleties involved in the debate over the reduction of skilled to simple labor, a task which exceeds the scope of this section. ${ }^{10}$ However, this discussion should suffice to shed light on the gist of the solution to this long-standing difficulty in Marxist value theory: the rigorous identification of the opening and closing phases of each capital-determined cycle of social production and consumption and, as a consequence, of the exact amount of privately performed socially necessary abstract labor that is required for the production of each particular commodity.

\section{Conclusion}

This article has critically examined the rejection of the commodity-nature of labor-power based on the broad argument that it is not produced under the direct command of capital. Although its lineage can be traced back to the early 20th century, this long-standing argument gained new life recently in association with the so-called New Solution approach to the transformation problem. This perspective has encountered some valid critical reactions which, however, have not offered a solid and conclusive alternative. In light of this, we took up the challenge and attempted to develop an explanation of the fully-fledged commodity-character of labor-power on the basis of Marx's own analysis of the value-form but beyond what he explicitly stated in Capital.

In a nutshell, our contribution revolved around the clear identification and differentiation of the specific social character of all the labor involved in the production of labor-power, from the point of view of the reproduction of the total social capital. It is the latter which, as the

10 One of the issues not addressed in this paper is the consistency of the different solutions with the scarce number of quotes by Marx that treat the subject of skilled labor. For instance, in one highly controversial passage Marx states that the respective rates of surplus value of skilled and simple labor are equal (Marx, 1981, 241). From our perspective, Marx was probably assuming that the use-values needed for the daily reproduction of each type of labor-power are identical, so that if the skilled laborer expends a working day at home to acquire the skills, the subsequent expenditure of skilled labor-power will objectify twice the amount of value. But since his/her labor-power will have cost twice, the rate of surplus value will remain the same. 
general social relation presiding over the movement of present-day society, gives unity and content to the human life-process. The crucial upshot of this for the purpose of grasping the commodity-nature of labor-power was two-fold. First, only privately undertaken social labor can form the value of labor-power. Second, when subsumed under the overall movement of the total social capital's reproduction, the privately performed labor required for labor-power's production attains final validation of its social usefulness only when it is exploited by capital in the direct process of production. This was the key link to explain the reappearance of the value of means of subsistence as the value of labor-power. On these grounds, we were able to reach the same conclusion that Marx reaches in Chapter 6 of Volume I of Capital, namely, that the value of labor-power is determined, just "as in the case of every other commodity," by the (privately performed) socially necessary labor for its production. However, unlike Marx's unmediated assertion, we unfolded all the mediations that are necessary to validate that claim.

As we have seen, this approach to the value of labor-power not only offers a way of grounding one of the fundamental categories of the critique of political economy. In addition, it provides useful tools to overcome the impasse reached within two classic Marxist controversies that have an intimate connection with the social processes underlying the production of labor-power and its form-determinations as a commodity, both as a value and as a use-value: the debate on domestic labor and the debate on skilled labor. Regarding the former, we have seen that our approach can shed light on the only reason why domestic labor is not value-producing. Briefly put, it is a part of social labor that is organized through direct personal relations, i.e., that is not privately performed vis-à-vis the consumer of its product. As for skilled labor, we showed that the only way to be consistent with its definition while avoiding the confusion between the value and the use-value of skilled labor-power, is to grasp that only the "formative labor" undertaken by the wage-laborer himself/herself is private vis-à-vis the final consumer of the commodity that he/she will eventually produce under the command of capital. For this reason, only this privately performed socially necessary labor must be added to the productive living labor of the skilled worker in order to determine the value of its product. In sum, we have seen that in both the case of domestic labor and that of skilled labor, the key to resolve the issues that gave rise to the 
respective debates, consists in the clear understanding of the part that they play in the overall cycle of valorization of capital.

Guido Starosta:

Departamento de Economía y Administración

Universidad Nacional de Quilmes

Roque Sáenz Peña 352

1876BXD

Bernal, Buenos Aires

Argentina

guido.starosta@unq.edu.ar

Gastón Caligaris:

Departamento de Economía y Administración

Universidad Nacional de Quilmes

Roque Sáenz Peña 352

1876BXD

Bernal, Buenos Aires

Argentina

gcaligaris@gmail.com

\section{REFERENCES}

Arthur, Christopher J. 2006. "The Inner Totality of Capitalism.” Historical Materialism, $14: 3,85-111$.

Carchedi, Guglielmo. 1991. Frontiers of Political Economy. London: Verso.

Bauer, Otto. 1906. “Qualifizierte Arbeit und Kapitalismus.” Die Neue Zeit: Wochenschrift der Deutschen Sozialdemokratie, 24, 644-657.

Benston, Margaret. 1969. "The Political Economy of Women's Liberation.” Monthly Review, 21:4, 13-27.

Bernstein, Eduard. 1900. "Zur Theorie des Arbeitswerths." Die Neue Zeit: Revue des Geistigen und Öffentlichen Lebens, 18, 356-363.

Bidet, Jacques. 2007 (1985). Exploring Marx's Capital: Philosophical, Economic, and Political Dimensions. Leiden, Amsterdam: Brill.

Böhm-Bawerk, Eugen. 1890 (1884). Capital and Interest. A Critical History of Economical Theory. London: Macmillan.

—_ 1949 (1896). "Karl Marx and the Close of his System." Pp. 1-118 in Paul M. Sweezy, ed., Karl Marx and the Close of His System, by Eugen Von Bohm-Bawerk Ẽ BohmBawerk's Criticism of Karl Marx, by Rudolf Hilferding. New York: Augustus M. Kelley.

Bortkiewicz, Ladislaus. 1952 (1907). "Value and Price in the Marxian System." International Economic Papers, 2, 5-60.

Bowles, Samuel, and Herbert Gintis. 1981. "Structure and Practice in the Labor Theory of Value." Review of Radical Political Economics, 12:4, 1-26.

Castoriadis, Cornelius. 1988 (1959). "Modern Capitalism and Revolution.” Pp. 226- 
343 in Cornelius Castoriadis, Political and Social Writings. Minneapolis, Minnesota: University of Minnesota.

Dalla Costa, Mariarosa, and Selma James. 1972. The Power of Women and the Subversion of the Community. Bristol, England: Falling Wall Press.

Dumenil, Gerard. 1983. "Beyond the Transformation Riddle: A Labor Theory of Value.” Science E् Society, 47:4 (Winter), 427-450.

Fine, Ben. 1988. Labor Market Theory: A Constructive Reassessment. London: Routledge.

Fine, Ben, Costas Lapavitsas, and Alfredo Saad-Filho. 2002. "Transforming the Transformation Problem: Why the 'New Interpretation' Is a Wrong Turning." Review of Radical Political Economics, 36:1, 3-19.

Foley, Dunkan K. 1982. "The Value of Money the Value of Labor Power and the Marxian Transformation Problem." Review of Radical Political Economics, 14:2, 37-47.

Gardiner, Jean. 1976. "The Political Economy of Domestic Labor in Capitalist Society." Pp. 109-120 in Diana Barker and Sheila Allen, eds., Dependence and Exploitation in Work and Marriage. London: Longman.

Harrison, John. 1973. "Political Economy of Housework." Bulletin of the Conference of Socialist Economists, 2:1, 35-52.

Harvey, David. 1982. Limits to Capital. Oxford, England: Blackwell.

Harvey, Philip. 1983. "Marx's Theory of the Value of Labor Power: An Assessment." Social Research, 50:2, 305-344.

Harvey, Philip. 1985. "The Value-Creating Capacity of Skilled Labor in Marxian Economics." Review of Radical Political Economics, 17:1-2, 83-102.

Hilferding, Rudolf. 1949 (1904). "Böhm-Bawerk's Criticism of Marx.” Pp. 119-196 in Paul M. Sweezy, ed., Karl Marx and the Close of His System, by Eugen Von BohmBawerk $\mathcal{E}$ Bohm-Bawerk's Criticism of Karl Marx, by Rudolf Hilferding. New York: Augustus M. Kelley.

Himmelweit, Susan, and Simon Mohun. 1977. "Domestic Labor and Capital." Cambridge Journal of Economics, 1:1, 15-31.

Inman, Mary. 1942. Woman-Power. Los Angeles, California: Committee to Organize the Advancement of Women.

Iñigo Carrera, Juan. 1995. De la Simple Mercancía a la Mercancía-Capital: La Transformación de los Valores en Precios de Producción. Ciudad de Buenos Aires: CICP.

Itoh, Makoto. 1987. "Skilled Labor in Value Theory." Capital and Class, 11:1, 39-58.

Jevons, William S. 1871. The Theory of Political Economy. London: Macmillan.

Keynes, John M. 1936. The General Theory of Employment, Interest, and Money. New York: Harcourt, Brace.

Kicillof, Axel, and Guido Starosta. 2007a. "On Materiality and Social Form: A Political Critique of Rubin's Value-Form Theory.” Historical Materialism, 15:3, 9-43.

— 2007b. "Value Form and Class Struggle: A Critique of the Autonomist Theory of Value." Capital E Class, 31:2, 13-40.

Krätke, Michael. 2009. "A Very Political Political Economist: Rosa Luxemburg's Theory of Wages." Pp. 139-174 in Riccardo Bellofiore, ed., Rosa Luxemburg and the Critique of Political Economy. Oxford, England: Routledge.

Lipietz, Alain. 1982. “The So-Called 'Transformation Problem' Revisited.” Journal of Economic Theory, 26:1, 59-88.

Marx, Karl. 1976a (1867). Capital. Volume I. Harmondsworth, England: Penguin. 
. 1976b (1863-1864). "Results of the Immediate Process of Production." Pp. 941-1084 in Karl Marx, Capital. Volume I. Harmondsworth, England: Penguin.

- 1981 (1895). Capital. Volume III. Harmondsworth, England: Penguin.

- 1987a (1867). "Marx to Johann Phillip Becker, April 17, 1867.” Pp. 358-359 in Karl Marx and Friedrich Engels, Collected Works. Volume 42. New York: International Publishers.

. 1987b (1858). "The Original Text of the Second and the Beginning of the Third Chapter of a Contribution to the Critique of Political Economy." Pp. 430-508 in Karl Marx and Friedrich Engels, Collected Works. Volume 29. New York: International Publishers.

—_ 1988 (1861-1863). "Economic Manuscript of 1861-63.” In Karl Marx and Friedrich Engels, Collected Works. Volume 30. New York: International Publishers. Mavroudeas, Stavros. 2001. "The Monetary Equivalent of Labor and Certain Issues Regarding Money and the Value of Labor-power.” Economie Appliquée, LIV:1, $37-54$

Meek, Ronald L. 1956. Studies in the Labor Theory of Value. London: Lawrence \& Wishart.

Mohun, Simon. 1994. "A Re(in)statement of the Labor Theory of Value." Cambridge Journal of Economics, 18:4, 391-412.

Morishima, Michio. 1973. Marx's Economics: A Dual Theory of Value and Growth. Cambridge: Cambridge University Press.

Morton, Peggy. 1971. “A Woman's Work is Never Done.” Pp. 211-227 in Edith Altbach, ed., From Feminism to Liberation. Cambridge, England: Schenkman Books.

Reuten, Geert, and Michael Williams. 1989. Value-Form, and the State. The Tendencies of Accumulation and the Determination of Economic Policy in Capitalist Society. London/ New York: Routledge.

Ricardo, David. 1821. On the Principles of Political Economy and Taxation. London: John Murray, Albemarle-Street.

Robles Baez, Mario L. 2011. Marx: Lógica y Capital. La Dialéctica de la Tasa de Ganancia y la Forma-Precio. México: Universidad Autónoma Metropolitana.

Rowthorn, Bob. 1974. "Skilled Labor in the Marxist System." Bulletin of the Conference of Socialist Economists, 8 (Spring), 25-45.

Saad-Filho, Alfredo. 2002. The Value of Marx: Political Economy for Contemporary Capitalism. London: Routledge.

Secombe, Wally. 1974. "The Housewife and Her Labor under Capitalism.” New Left Review I, 83, 3-24.

Smith, Paul. 1978. "Domestic Labor and Marx's Theory of Value." Pp. 199-219 in Annette Kuhn and AnnMarie Wolpe, eds., Feminism and Materialism: Women and Modes of Production. London: Routledge \& Kegan Paul.

Starosta, Guido. 2016 (forthcoming). Marx's Capital, Method and Revolutionary Subjectivity. Leiden, Amsterdam: Brill.

Sweezy, Paul M. 1942. The Theory of Capitalist Development: Principles of Marxian Political Economy. New York: Oxford University Press.

Thomas, Carol. 1987. Domestic Labor and the Capitalist Mode of Production: A Theoretical and Historical Analysis. PhD Thesis, University of Warwick. 
Tortajada, Ramón. 1977. "A Note on the Reduction of Complex Labor to Simple Labor." Capital and Class, 1:1, 106-116.

Vogel, Lise. 2000. "Domestic Labor Revisited.” Science E゚ Society, 64:2 (Summer), 151-170.

von Werlhof, Claudia. 1988. "Women's Work: The Blind Spot in the Critique of Political Economy." Pp. 13-16 in Maria Mies, Veronika Bennholdt-Thomsen and Claudia von Werlhof, eds., Women: The Last Colony. London: Zed Books. 